Article

\title{
Performance Analysis of Log Extraction by a Small Shovel Operation in Steep Forests of South Korea
}

\author{
Eunjai Lee ${ }^{1}$, Sang-Kyun Han $^{2}$ and Sangjun $\operatorname{Im}^{3, *}$ \\ 1 National Institute of Forest Science, Forest Technology and Management Research Center, \\ 498 Gwangneungsumogwon-ro, Soheul-eup, Pocheon 11186, Korea \\ 2 Department of Forestry and Landscape Architecture, Korea National College of Agriculture and Fisheries, \\ 1515 Kongjwipatwji-ro, Deokjin-gu, Jeonju 54874, Korea \\ 3 Department of Forest Sciences and Research Institute of Agriculture and Life Sciences, Seoul National \\ University, 1 Gwanak-ro, Gwanak-gu, Seoul 08826, Korea \\ * Correspondence: junie@snu.ac.kr; Tel.: +82-2-880-4768
}

Received: 7 May 2019; Accepted: 11 July 2019; Published: 13 July 2019

check for updates

\begin{abstract}
In South Korea, logs for low-value products, such as pulpwood and fuelwood, are primarily extracted from harvest sites and transported to roadside or landing areas using small shovels. Previous studies on log extraction, however, have focused on cable yarding operations with the goal of improving productivity on steep slopes and inaccessible sites, leaving small-shovel operations relatively unexamined. Therefore, the main objectives were to determine small-shovel extraction productivity and costs and to evaluate the impact of related variables on productivity. In addition, we developed a model to estimate productivity under various site conditions. The study took place in 30 case study areas; each area has trees with stems at a diameter at breast height ranging from 18 to $32 \mathrm{~cm}$ and a steep slope (greater than 15\%). The areas ranged from 241 to 1129 trees per hectare, with conifer, deciduous, and mixed stands. Small-shovel drives ranged from 36 to $72 \mathrm{~m}$ per extraction cycle from stump to landing. The results indicated that the mean extraction productivity of small-shovel operations ranged between 2.44 to $9.85 \mathrm{~m}^{3}$ per scheduled machine hour (including all delays). At the forest level, the estimated average stump-to-forest road log production costs were US $\$ 4.37$ to $17.66 / \mathrm{m}^{3}$. Small-shovel productivity was significantly correlated with stem size (diameter at breast height and tree volume) and total travelled distance (TTD). However, a Pearson's correlation analysis indicated that stand density and slope did not have a significant effect on productivity. Our findings provide insights into how stem size and TTD influence small shovel performance and the predictive ability of productivity. Further, this information may be a valuable asset to forest planners and managers.
\end{abstract}

Keywords: shovel logging; follow-up study; cut-to-length extraction; productivity; cost; scheduled machine hour

\section{Introduction}

Logging operations (a.k.a., primary transportation), in which logs are transported from stumps to a designated roadside or central landing area using various extraction methods, are an important part of the timber harvesting process, but they can be extremely expensive and more time-consuming in practice than felling and processing [1-4]. Many studies have examined the performance of extraction methods on sites with differing characteristics in order to establish the logistics of extraction activities, such as ground-based extraction (skidding and forwarding) [5-8] and cable yarding [8-10]. It can be concluded from these studies that logging practices should be economically determined while maintaining a deep understanding of both the potential and limitations of the chosen method. 
Time-and-motion studies have been widely used to evaluate the performance of individual logging equipment as well as entire harvesting systems [11,12]. This type of study has been essential for predicting machine productivity and utilization rates in various scenarios under similar working conditions $[13,14]$. However, this approach is limited in terms of data availability due to the relatively short period of data collection and high costs of field work [14-16]. Additionally, a number of past studies have assessed performance using the follow-up method, which utilizes historic output records, such as productivity and costs. This can provide more accurate information on long-term performance than time-and-motion studies [17-19].

In the Republic of Korea (a.k.a., South Korea), forest land covers an area of 6.3 million hectares (64\% of the total land area), and approximately $80 \%$ of all forested areas are on steep terrain with slopes greater than $40 \%$ [20]. In 2017, the stand density was $154.1 \mathrm{~m}^{3} / \mathrm{ha}$, with conifers being the dominant species, namely the Korean red pine (Pinus densiflora), Japanese larch (Larix kaempferi [Lamb.] Carrière), and pitch pine (Pinus rigida Mill). The volume of timber harvested has considerably increased in recent years: from 1.3 million $\mathrm{m}^{3}$ in 2013 to 2.2 million $\mathrm{m}^{3}$ in 2017 [20].

Two harvesting methods are commonly used in South Korea: cut-to-length small-shovel production (CTL-S) and tree-length cable-yarder production harvesting (TL-C). There are a number of past studies that investigate the TL-C method to describe, understand, and improve upon the efficiency of $\log$ production and associated operational decisions. Other studies focus on the productivity and operation efficiency of individual machines [21,22], comparing extraction performances among different cable-yarder technologies $[23,24]$, and the effect of yarding direction (uphill vs. downhill) on productivity and cost $[10,25]$ in order to support operational decisions. However, the use of the TL-C method for log hauling activities remains limited since this method requires not only a high skill level, but also an inherently high level of investment [26]. Thus, cable yarding systems have rarely been implemented on steep slopes and remote areas due to operation costs.

In South Korea, CTL-S is the preferred system, and it has replaced TL-C on steep slopes. After felling and processing trees with a chainsaw, 2-4 $\mathrm{m}$ logs are extracted using a small shovel, which is a small-sized hydraulic excavator ( 5.0 metric tons in weight with a $0.2 \mathrm{~m}^{3}$ bucket) with a log grapple (i.e., a small shovel or wood grab; Figure 1). Generally, small-shovel (SS) extraction activities use gravitational energy to transport logs from the stump to the roadside/landing area. For example, on steep terrain, gravity can be useful in assisting with throwing, sliding, and rolling logs downhill [3,27]. Thus, the small shovel-based logging method could be increasingly applied in Korea's harvesting operations, but the productivity level and costs associated with extracting $2-4 \mathrm{~m}$ logs using SS activities remains unclear.

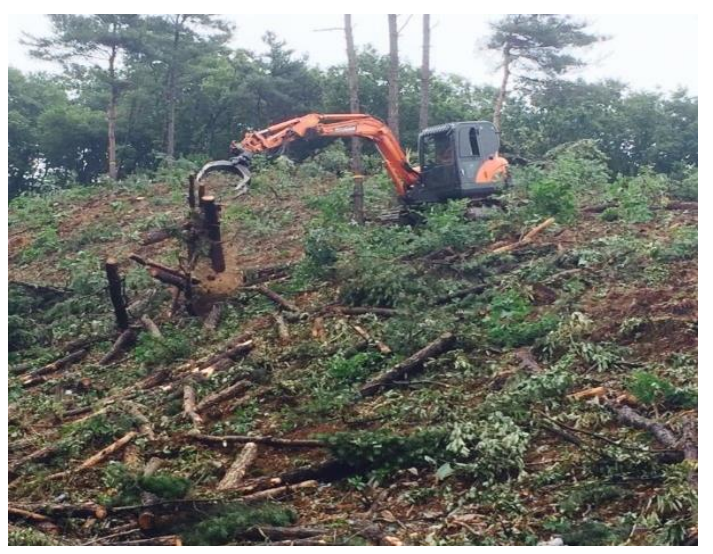

Figure 1. Log extraction using a small shovel-mounted steel-track excavator with a log grapple (1.3 m maximum jaw opening and $0.1 \mathrm{~m}$ closed jar gap); the boom length of the excavator is $5.1 \mathrm{~m}$ (Photo create: E. Lee). 
Therefore, in this study, the overall objective was to determine the performance of SSs in various types of forest. In particular, this study sought to: (1) determine the productivity $\left(\mathrm{m}^{3} / \mathrm{SMH}\right)$ and costs (US $\$ / \mathrm{m}^{3}$ ) of extracting logs through the follow-up method, (2) establish the influential variables in SS extraction productivity, and (3) develop regression models to predict SS productivity. Further, the results of this study will lead to better-informed SS technology decisions and more efficient production of timber products.

\section{Materials and Methods}

In collaboration with a group of logging companies and contractors under the Korea Wood Products Association (KWPA), we conducted a follow-up study of SS extraction activity, which is becoming the prevailing extraction technology. The study focused on the production of CTL clear-cut harvest units (CHUs) in the Central Northeast region of South Korea (Gangwon-do, Gyeonggi-do, Chungcheongbuk-do, and Gyeongsangbuk-do; Figure 2). The main characteristics of the CHUs are presented in Table 1 . The units are located on relatively steep terrain (ranging from 13 to $64 \%$, with an average slope of $49 \%$ ); trees in these areas have a DBH (diameter at breast height) of up to $32 \mathrm{~cm}$ (minimum DBH, $18 \mathrm{~cm}$ ). On average, the units have 560 trees per hectare (TPH), and the range is from 241 to $1129 \mathrm{TPH}$. The data set covered the dominant forest stand types: conifer, deciduous, and mixed. The total traveled distance (TTD; a.k.a., total driven distance) ranged from 36 to $72 \mathrm{~m}$ and average road density was $108 \mathrm{~m} /$ ha (ranged from 32 to $188 \mathrm{~m} /$ ha). We defined TTD for small-shovel operations as the distance the extractor travels, starting when the small shovel leaves the forest road or landing area and ending when it returns to the landing (Figure 3). The study areas were selected to cover a wide range of forest conditions; this was done to achieve an enhanced understanding of small shovel extraction performance across South Korea.

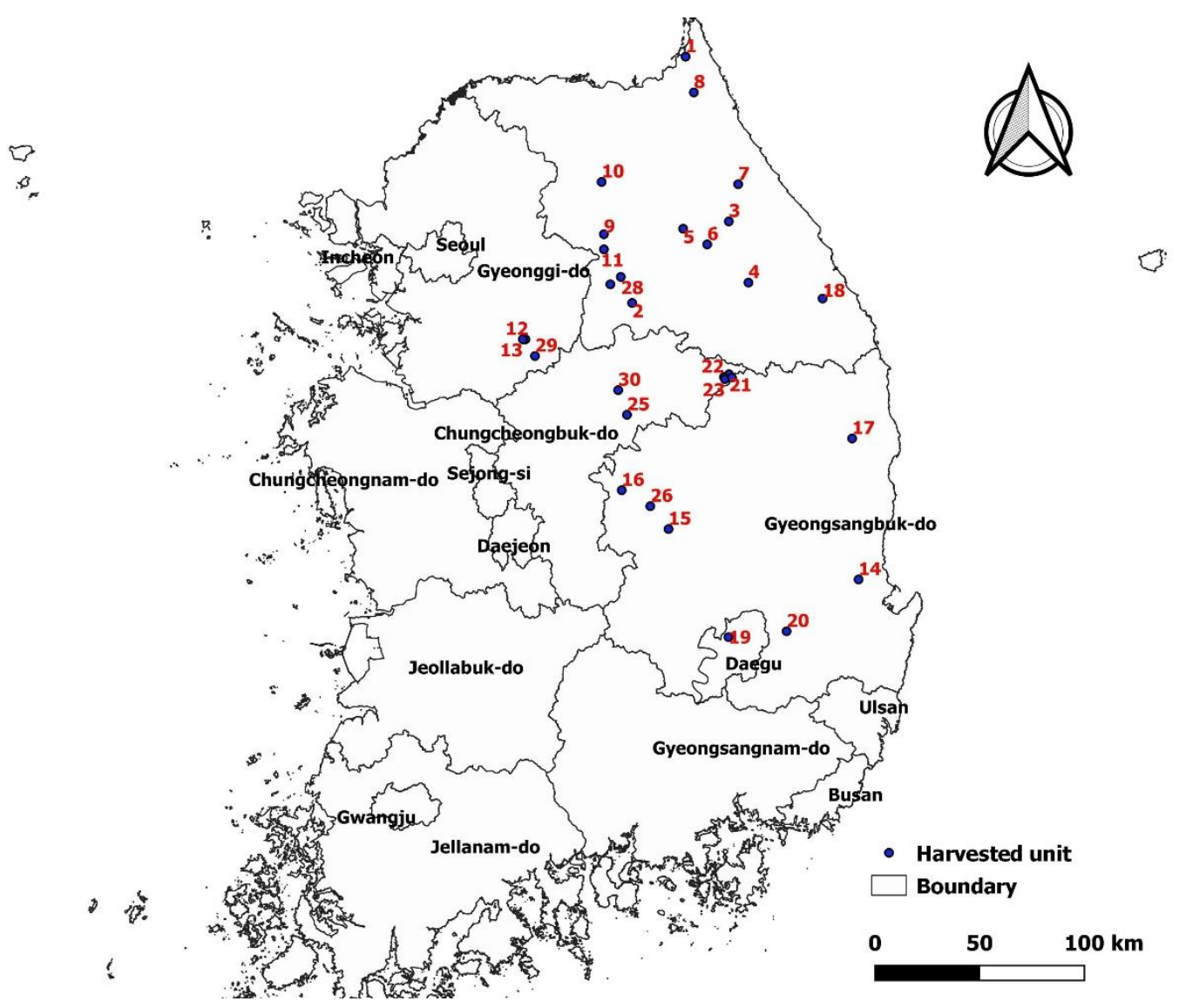

Figure 2. Map of study sites in South Korea showing the harvesting units. 
Table 1. Summary of information collected for each unit: post-harvesting stand characteristics, average total travelled distance, and productivity.

\begin{tabular}{|c|c|c|c|c|c|c|c|c|}
\hline \multirow{2}{*}{$\begin{array}{l}\text { Harvest } \\
\text { Unit No. }\end{array}$} & \multirow{2}{*}{$\begin{array}{l}\text { Stand } \\
\text { Type }\end{array}$} & \multirow{2}{*}{$\begin{array}{c}\text { Average } \\
\text { DBH }^{\mathrm{a}} \\
(\mathrm{cm})\end{array}$} & \multicolumn{2}{|c|}{$\begin{array}{c}\text { Average } \\
\text { Volume }\left(\mathrm{m}^{3}\right)\end{array}$} & \multirow{2}{*}{$\begin{array}{c}\text { Stand } \\
\text { Density } \\
\text { (Trees/ha) }\end{array}$} & \multirow{2}{*}{$\begin{array}{c}\text { Average } \\
\text { Slope } \\
(\%)\end{array}$} & \multirow{2}{*}{$\begin{array}{c}\text { Average Total } \\
\text { Travelled } \\
\text { Distance (m) }\end{array}$} & \multirow[t]{2}{*}{$\begin{array}{l}\text { Productivity } \\
\left(\mathrm{m}^{3} / \text { day }\right)\end{array}$} \\
\hline & & & tree $^{-1}$ & $\mathrm{ha}^{-1}$ & & & & \\
\hline 1 & Deciduous & 22 & 0.26 & 112 & 435 & 64 & 58 & 50.9 \\
\hline 2 & Deciduous & 22 & 0.26 & 119 & 466 & 60 & 60 & 58.4 \\
\hline 3 & Conifer & 20 & 0.20 & 155 & 756 & 42 & 64 & 59.8 \\
\hline 4 & Conifer & 22 & 0.24 & 271 & 1129 & 52 & 68 & 58.6 \\
\hline 5 & Conifer & 24 & 0.34 & 148 & 436 & 42 & 44 & 44.1 \\
\hline 6 & Conifer & 18 & 0.14 & 155 & 1,107 & 64 & 42 & 26.3 \\
\hline 7 & Conifer & 24 & 0.30 & 188 & 627 & 32 & 69 & 75.5 \\
\hline 8 & Deciduous & 32 & 0.56 & 157 & 278 & 64 & 55 & 52.7 \\
\hline 9 & Conifer & 22 & 0.25 & 190 & 760 & 32 & 61 & 60.3 \\
\hline 10 & Deciduous & 18 & 0.14 & 105 & 755 & 64 & 43 & 19.5 \\
\hline 11 & Mix & 22 & 0.25 & 113 & 450 & 42 & 45 & 40.2 \\
\hline 12 & Mix & 18 & 0.15 & 96 & 650 & 13 & 43 & 47.0 \\
\hline 13 & Mix & 22 & 0.23 & 97 & 418 & 32 & 58 & 66.8 \\
\hline 14 & Mix & 24 & 0.30 & 97 & 320 & 32 & 55 & 55.8 \\
\hline 15 & Deciduous & 24 & 0.28 & 68 & 241 & 52 & 56 & 57.4 \\
\hline 16 & Deciduous & 24 & 0.29 & 138 & 476 & 42 & 45 & 33.7 \\
\hline 17 & Deciduous & 20 & 0.19 & 83 & 442 & 64 & 46 & 35.0 \\
\hline 18 & Deciduous & 22 & 0.23 & 69 & 296 & 60 & 46 & 45.1 \\
\hline 19 & Conifer & 18 & 0.16 & 118 & 716 & 42 & 53 & 26.1 \\
\hline 20 & Deciduous & 24 & 0.28 & 72 & 255 & 42 & 42 & 37.7 \\
\hline 21 & Mix & 18 & 0.18 & 161 & 909 & 40 & 45 & 42.4 \\
\hline 22 & Mix & 32 & 0.60 & 169 & 282 & 64 & 72 & 78.8 \\
\hline 23 & Mix & 32 & 0.56 & 162 & 287 & 60 & 65 & 71.8 \\
\hline 24 & Mix & 20 & 0.19 & 121 & 626 & 52 & 36 & 33.8 \\
\hline 25 & Deciduous & 18 & 0.16 & 134 & 819 & 64 & 61 & 50.9 \\
\hline 26 & Deciduous & 24 & 0.27 & 124 & 459 & 52 & 39 & 43.3 \\
\hline 27 & Deciduous & 18 & 0.15 & 62 & 408 & 52 & 41 & 22.8 \\
\hline 28 & Mix & 24 & 0.27 & 154 & 580 & 64 & 44 & 43.4 \\
\hline 29 & Mix & 22 & 0.22 & 77 & 344 & 22 & 45 & 48.9 \\
\hline 30 & Conifer & 26 & 0.36 & 201 & 558 & 64 & 55 & 60.7 \\
\hline
\end{tabular}

${ }^{\text {a }}$ DBH: Diameter at breast height.

CTL-S clear-cutting operations in each unit were performed using a semi-mechanized system that employs a chainsaw for felling, delimbing, and bucking trees into 2-4 $\mathrm{m}$ logs, which are mostly used as pulpwood. (An alternative to the use of the SS, especially on steep slopes, is manipulating all logs at the stump, as described by Lee et al. $[10,28]$.) The SS operation utilized the gravity extraction technique, which involves throwing, rolling, and pushing logs, to move the logs to the roadside or landing area. When SS travels up and down, the machine moves along the slope direction. For each unit, timber harvesting had a similar target: (1) support sustainable forest management to ensure future availability and (2) benefit domestic timber industries by increasing the self-sufficiency rate.

Three years of historical data, from the period of 2015 to 2017, were manually collected from logging companies. The collected dataset includes a detailed description of harvest unit characteristics and the net production rate $\left(\mathrm{m}^{3} /\right.$ day, based on an 8 -hour work day) of log extraction by SS operation (Table 1). SS extraction productivity was determined by two processes: (1) the sorting of $2-4 \mathrm{~m}$ logs when the SS commences travel into the felling site from the roadside/landing area and (2) the throwing and pushing of logs while the SS returns to the roadside/landing area. 


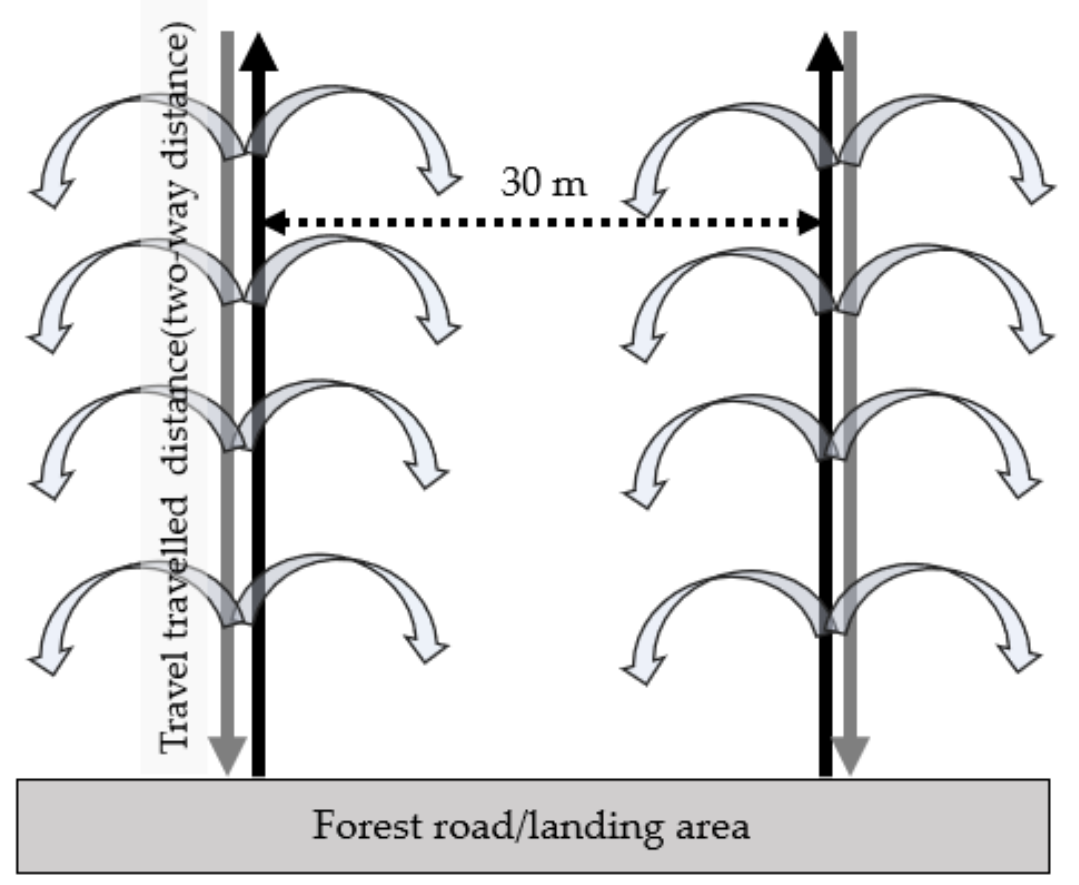

Figure 3. Vertical pattern for small shovel extraction activity cut-to-length to forest road/landing area and for operation in steeply sloped forests in South Korea.

In this study, the follow-up data collection method conducted did not involve a time-and-motion measuring device. This study relied solely on historical data from extraction operations performed by forest contractors. There was no information available on delay times, including mechanical, operational, or personal delays. Therefore, scheduled machine hours $(\mathrm{SMH})$ were used to evaluate the productivity and cost of SS operations.

The costs for owning and operating SSs were calculated with the method developed by Miyata [29], which is a commonly accepted machine rate calculation technique. In addition to costs associated with machine ownership, operation, and labor, we included machine delays (mechanical, operational, and personal) and warm-up costs. This is necessary because the productivity data, which is divided into two categories: machine operation and idle time, is per SMH. The machine utilization rate, labor cost, and fuel consumption rate were collected from the KWPA (Table 2). The overhead, profit allowance, and transportation costs associated with SS were not obtained.

The SPSS package (IBM Co., New York, NY, USA, v. 22.0) was used for statistical analysis. Pearson's correlation test was conducted to clarify how the independent variables (DBH, slope, and TTD) affect SS productivity. Based on the value of the correlation coefficients, a predictive equation of productivity per SMH was developed using the ordinary least squares regression technique. Two-thirds of the follow-up data were randomly selected for model development, while the remaining one-third of the data was applied for validation of the proposed model. A two-sample t-test was used to compare the predicted and observed values and to describe any statistical differences for model verification. 
Table 2. Cost components and estimated hourly cost to own and operate a small shovel.

\begin{tabular}{lc}
\hline Cost Component & Small Shovel \\
\hline Purchase price (US \$) & $54,000.00$ \\
Salvage value (\%) & 20 \\
Economic life (year) & 7 \\
Scheduled machine hour per year & 1400 \\
Interests (\%) & 10 \\
Insurance (\%) & 3 \\
Taxes (\%) & 2 \\
Fuel consumption rate (liter/hour) & 9.0 \\
Fuel cost (US \$/liter) & 1.20 \\
Lubrication (\% of fuel cost) & 40 \\
Repair and maintenance $\%$ of depreciation) & 90 \\
Labor (US \$/hour) & 17.00 \\
Fringe benefit $(\%$ of labor) & 22 \\
Fixed cost (US \$/hour) & 8.21 \\
Operating cost (US \$/hour) & 14.52 \\
Labor cost (US \$/hour) & 20.35 \\
Total operation cost (US \$/hour) & 45.87 \\
\hline
\end{tabular}

\section{Results}

The study was designed to test the efficacy of SS extraction from stumps to roadside through 30 different case studies. Overall, the SS was capable of a productivity rate of 2.44 to $9.85 \mathrm{~m}^{3} / \mathrm{SMH}$ at a cost of US $\$ 4.37$ to $17.66 / \mathrm{m}^{3}$ (Figure 4 ). There were large variations in productivity and cost evaluations across the harvest units.

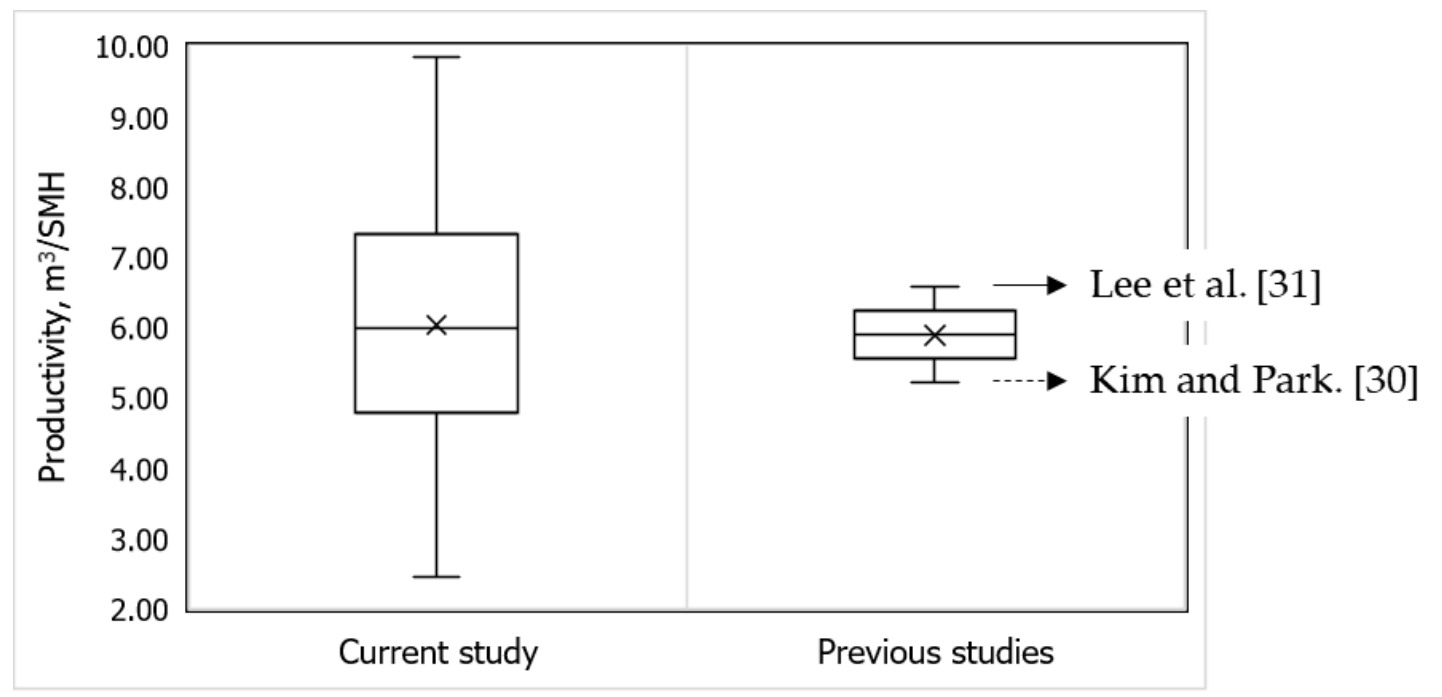

Figure 4. Box and whisker plots of productivity between the current study and previous studies: Kim and Park [30] and Lee et al. [31]; both studies evaluated the shovel logging productivity. The X indicates mean value.

Productivity may increase or decrease with variation in stem size, such as DBH and tree/log volume. Through Pearson's correlation test, we found that DBH and tree volume had a considerable impact on productivity $(p<0.001)$. Productivity and stem size, including $\mathrm{DBH}(r=0.6168)$ and tree volume $(r=0.6161)$, were directly related (Figures 5 and 6). 


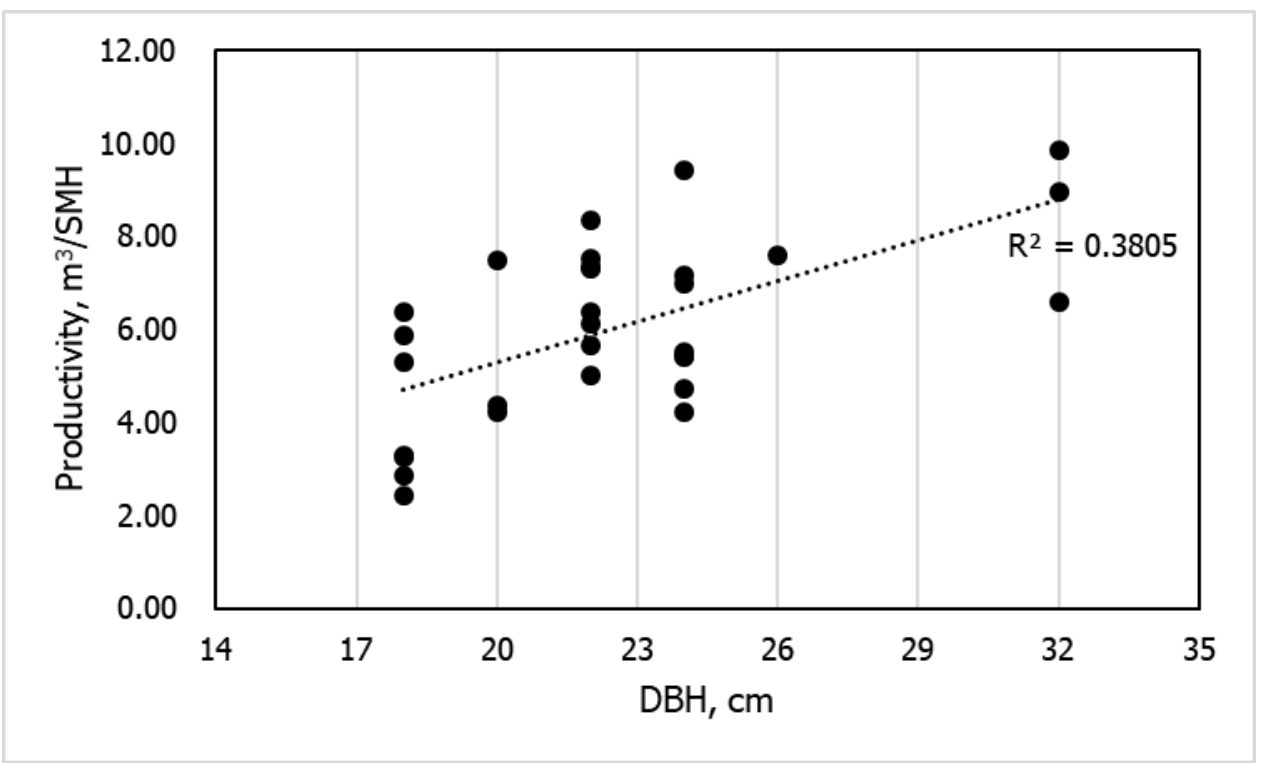

Figure 5. Productivity, which was calculated using follow-up data from 30 study areas, and its relationship with DBH (Diameter at Breast Height). Productivity had a moderate correlation with DBH.

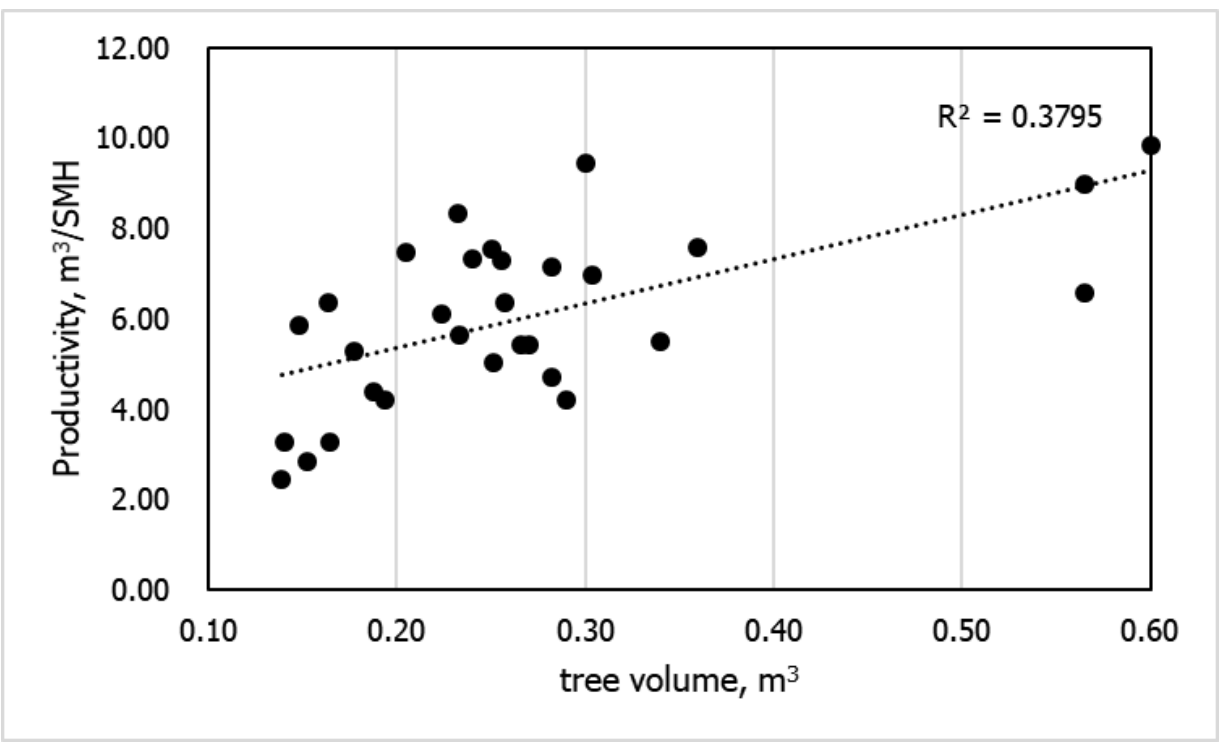

Figure 6. Productivity, which was calculated using follow-up data from 30 study areas, and its relationship with tree volume. Productivity had a moderate correlation with tree volume.

In most harvest units, a higher stand density is significantly associated with small stem size ( $p<0.001$; DBH of $r=-0.5830$ and tree volume of $r=-0.5322$ ). However, stand density had a weak to moderate negative correlation with SS productivity $(r=-0.2214$; Figure 7$)$. As a result, SS productivity was inversely correlated with stand density. 


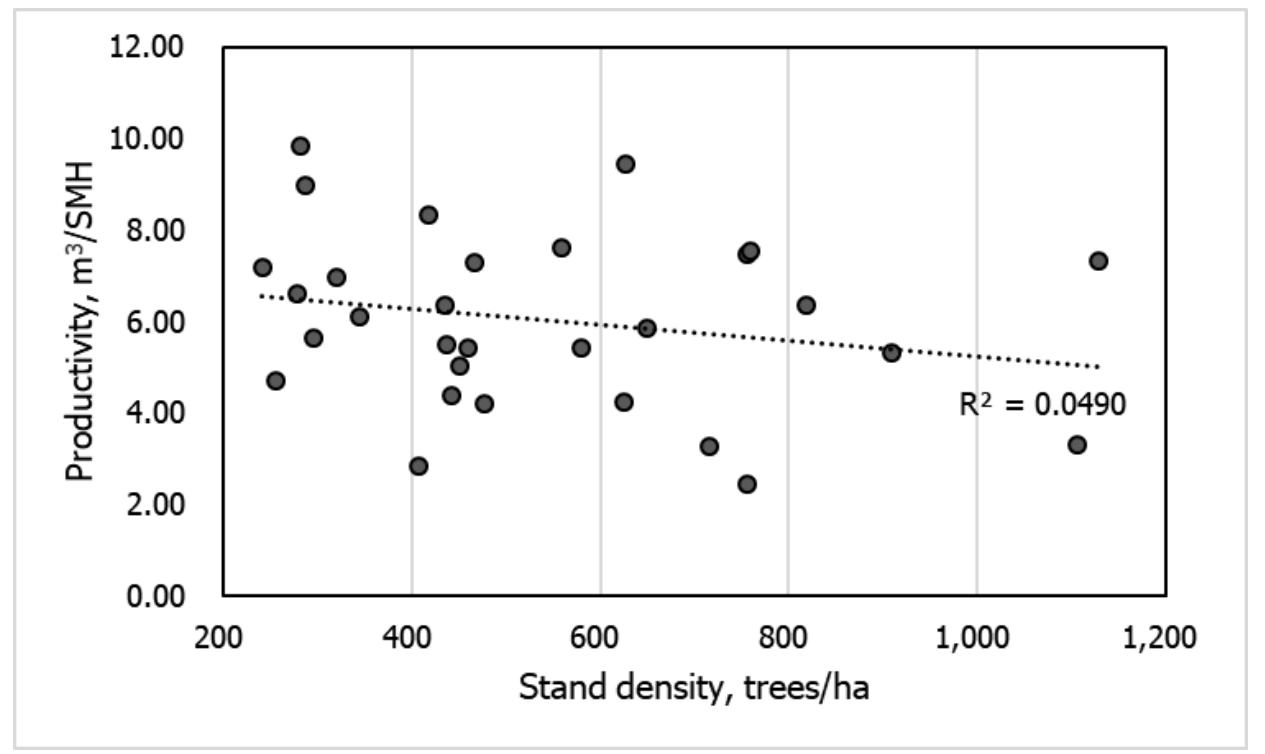

Figure 7. Productivity, which was calculated using follow-up data from 30 study areas, and its relationship with stand density. Productivity had no correlation with stand density.

This study implied that an increased TTD would be positively and significantly correlated with SS productivity $(p<0.001 ; r=0.8262$; Figure 8$)$. On the other hand, slope had no significant correlation with productivity $(r=-0.1060$; Figure 9$)$. Although our data is limited to divide into SS cycle elemental time, we found that the time spent throwing and rolling logs may be considerably longer than the travel time. Further, in terms of extraction activity, there was no common pattern across Korea for selecting SS operations in steeply-sloped forests.

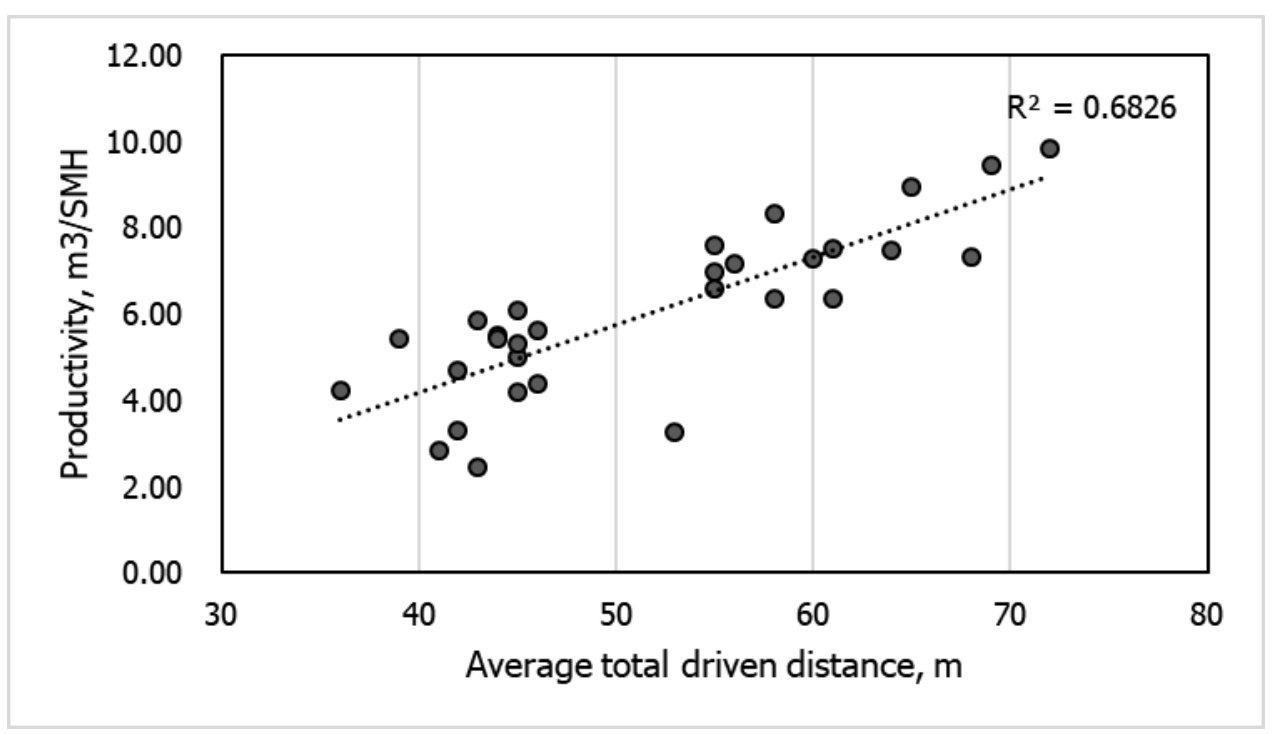

Figure 8. Productivity, which was calculated using follow-up data from 30 study areas, and its relationship with total travelled distance. Productivity had a strong correlation with average total travelled distance. 


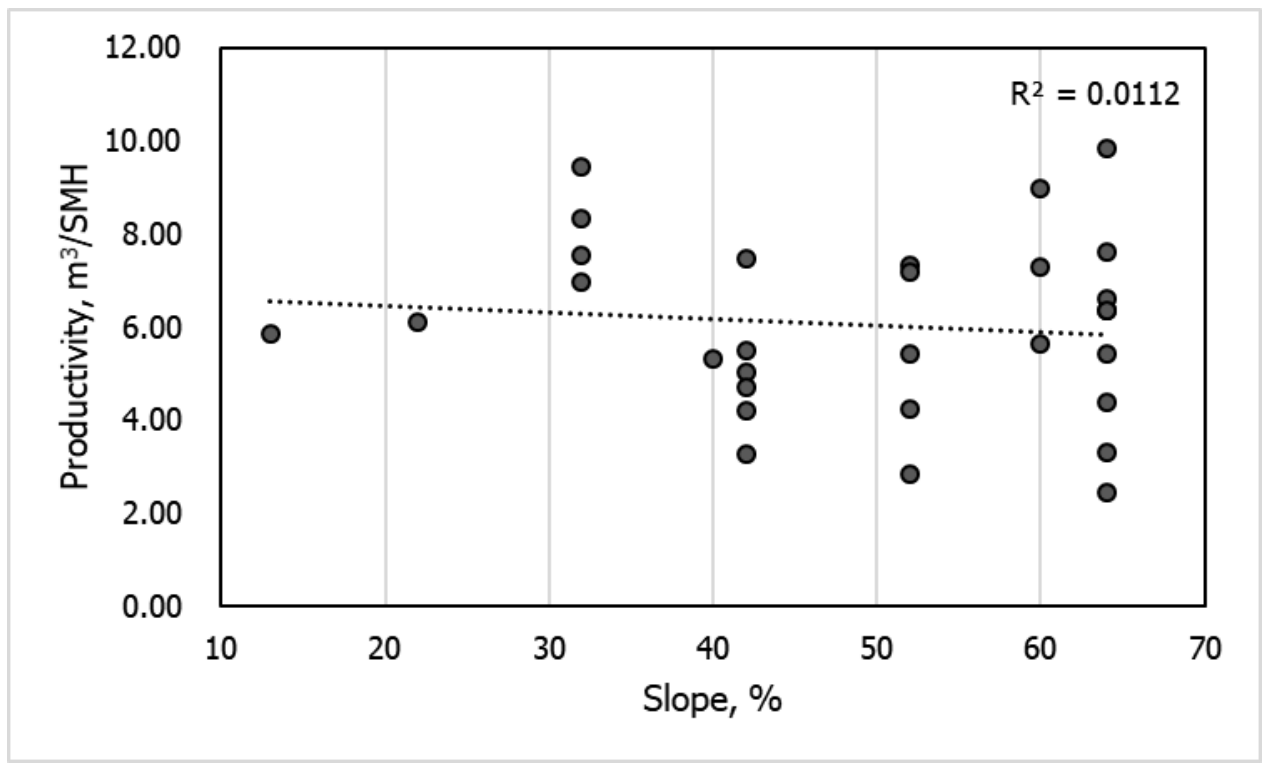

Figure 9. Productivity, which was calculated using follow-up data from 30 study areas, and its relationship with slope. Productivity had no correlation with slope.

The SS productivity regression equation was derived from the follow-up data to predict extraction productivity (Table 3). The independent variables ranged from 0.14 to $0.56 \mathrm{~m}^{3}$ for tree volume and 36 to $69 \mathrm{~m}$ for TTD. This model was tested for assumptions of normality, independence, and equal variance to confirm the validity of the analysis. The TTD was significant $(p<0.001)$ as a variable, but tree volume was not a significant variable $(p=0.0581)$. A paired t-test was performed to validate the equation against the observed data. The results indicated that the predicted value was not significantly different from the observed value $(p>0.05)$. Thus, the obtained model may be quite accurate.

Table 3. Productivity regression model for small-shovel operations extracting $2-4 \mathrm{~m}$ logs. Productivity is in $\mathrm{m}^{3} / \mathrm{SMH}$ (Scheduled Machine Hour). A paired t-test was used for model verification across observed data.

\begin{tabular}{|c|c|c|c|c|c|c|}
\hline Average Productivity Estimator & SE & $t$ & $p$-Value & $\begin{array}{l}\text { Model } \\
\text { adj. } R^{2}\end{array}$ & $\begin{array}{l}\text { Model } \\
p \text {-Value }\end{array}$ & $\begin{array}{l}\text { t-Test } \\
\text { ( } p \text {-Value) }\end{array}$ \\
\hline$=-2.1861$ & 0.9966 & -3.0810 & 0.0396 & 0.7517 & $<0.01$ & 0.2935 \\
\hline$+3.6873 \times$ Average tree volume $\left(\mathrm{m}^{3}\right)$ & 1.8400 & 2.2827 & 0.0581 & & & \\
\hline $\begin{array}{l}+0.1404 \times \text { Average total travelled } \\
\text { distance }(\mathrm{m})\end{array}$ & 0.0205 & 6.9908 & $<0.01$ & & & \\
\hline
\end{tabular}

The SS productivity model showed that productivity improved as tree volume and travelled distance increased; the average tree volume ranged from 0.15 to $0.50 \mathrm{~m}^{3}$, and the mean TTD was between 40 and $70 \mathrm{~m}$ (Figure 10). The data indicated that when the volume of trees extracted increased from $0.15 \mathrm{~m}^{3}$ to $0.50 \mathrm{~m}^{3}$ (and the TTD ranged between 40 and $70 \mathrm{~m}$ ), productivity increased by up to $30 \%$. This result may be explained by the fact that efficiency improved with larger tree volumes and an increased number of logs at the stump area. 


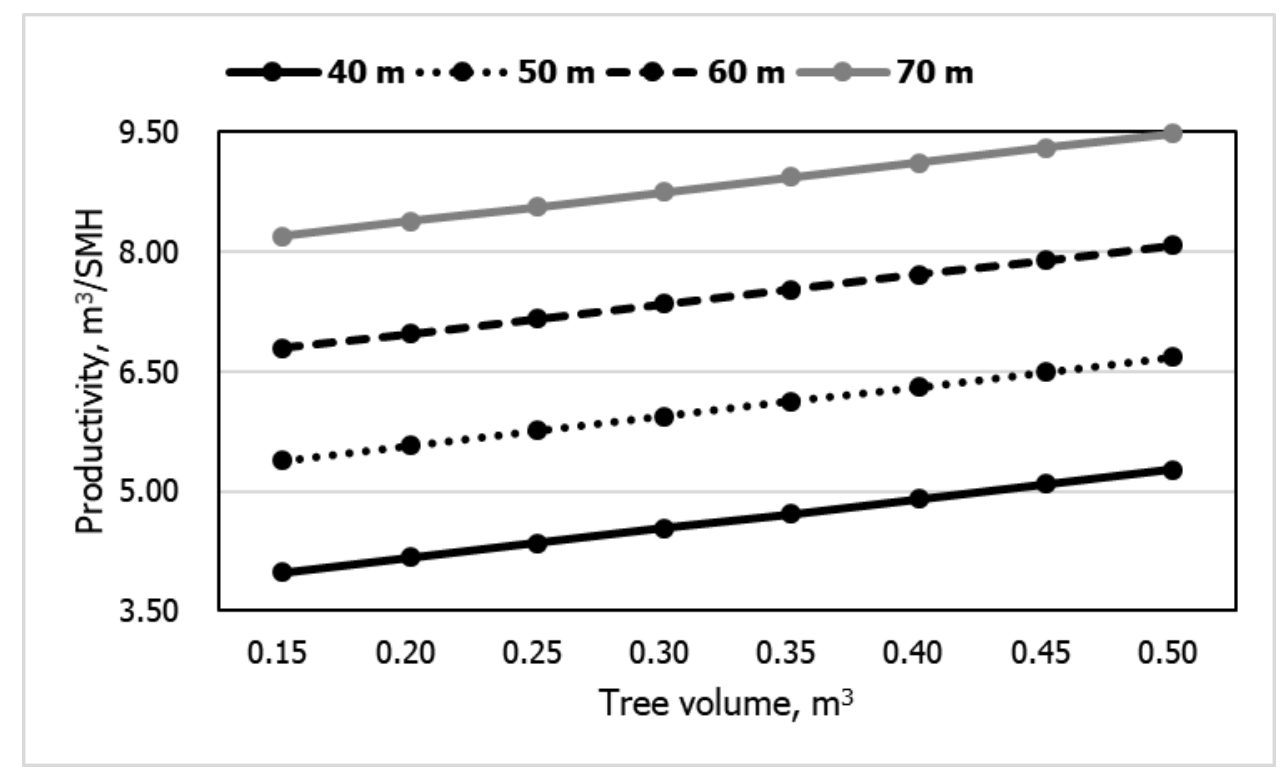

Figure 10. Productivity for the small-scale extraction operations in relation to tree volume $\left(\mathrm{m}^{3}\right)$ and total travelled distance $(\mathrm{m})$.

\section{Discussion}

Small-shovel logging method has become widespread and has had increasing use across South Korea in steeply-sloped forests. With steep terrain extraction, the slope grade helps in hauling the logs downhill with the support of gravity from the felling area [28,32]. We conducted a follow-up study of the SS extraction method to evaluate the productivity and cost under various types of forests and established the influential variables in extraction productivity. In addition, we developed a regression model for the SS to estimate hourly productivity in SMH. The results show that the estimated stump-to-forest road log productivity was between 2.44 and $9.85 \mathrm{~m}^{3} / \mathrm{SMH}$ at US $\$ 17.66$ and 4.37, respectively. The stem size and TTD statistically have an influence on the productivity of SS extraction operation $(p<0.001)$, but the slope had no static correlation $(r=-0.1060)$. Thus, the model showed that productivity improved as tree volume and TTD increased. Further, we examined a sensitivity analysis to evaluate the impact of the tree volume and TTD on the model. The result indicated that, when the volume of trees extracted increased from 0.15 to $0.50 \mathrm{~m}^{3}$, with the TTD ranging between 40 and $70 \mathrm{~m}$, productivity increased by up to $30 \%$.

In our study, mean SS extraction productivity was $6.03 \pm 1.90 \mathrm{~m}^{3} / \mathrm{SMH}$, which is very similar to the findings by Kim and Park [30] and Lee et al. [31], whose results were 5.21 and $6.57 \mathrm{~m}^{3} / \mathrm{SMH}$, respectively (Figure 4). These previous studies likely operated under similar conditions: an average $\mathrm{DBH}$ of 22 to $26 \mathrm{~cm}$, tree volume of 0.24 to $0.27 \mathrm{~m}^{3}$, and slope of 36 to $44 \%$. Thus, the follow-up evaluation is deemed reasonable and acceptable in terms of accurately determining the productivity of the SS extraction process.

The productivity and costs of SSs varied when extracting 2-4 $\mathrm{m}$ logs in steep terrain due to a wide range of forest types. Numerous studies have pointed out that differences in productivity and cost of extraction activities were due to locally variable conditions, including the volume of extracted logs, stem size, extraction distance, and working conditions [33-35]. Our data significantly showed that stem size and TTD were important key factors in SS productivity prediction, while the slope was not statistically correlated.

Shovel logging productivity is affected by the number of swings and road spacing [36]. Although our data was limited to determine the effect of number of swings and road spacing, we tested how the DBH, slope, and TTD affect SS productivity using Pearson's correlation. We found that stem size had a statistical impact on productivity. Numerous studies have pointed out that stem size has been a primary factor in extraction productivity $[11,34,37,38]$, because a larger log size 
increases the piece volume, payload, and productivity. Therefore, DBH and tree volume may be two of the main factors influencing SS productivity. Further, tree volume, instead of DBH, was selected in the regression model because this variable was evaluated as more stable and applicable $[17,39,40]$. Both the Berendt et al. [41] and Han et al. [42] studies found that the most commonly used variable is tree volume to estimate the productivity.

Another important variable that influences productivity was significantly related to extraction distance since the load travel time accounted for over one quarter of the variation in cycle time [43,44]. Thus, extraction productivity increases with a decrease in extraction distance [45-47]. However, our follow-up data provide only an average total travelled distance of SS across the harvest unit, while the extraction distance was not collected. We found that productivity and TTD were strongly correlated. These results are consistent with many published studies, such as Matthews et al., [48], Kumazawa et al., [49], and Berg et al., [50]. These studies posited that the driving unloading speed increases with an increase in driving distance. During extraction operation, operator's stress on long distances could lead to increase driving speed.

In addition, extraction productivity may be influenced by the number of logs $[46,50]$. This pattern could be explained by the fact that productivity increases with a decrease in the number of load stops and driven distances. The operation of SS in South Korea, unlike the excavator extraction method (a.k.a., shovel logging), uses gravity. During the operation, the throwing and rolling activity, which is done to transfer logs from the felling area down to the landing area, may be associated with a large number of logs and long TTD. Thus, the productivity of SS may depend on the number of throwing stops and TTDs.

Slope is shown to be a primary factor in productivity because it affects the accessibility of the harvesting machine [18,43,46,51,52]. However, this was also observed in Berendt et al. [41], Ghaffariyan et al. [53], and Walsh and Strandgard [54]. These studies found that the slope did not significantly impact loaded travel time during extraction activities. This study showed that slope had no statistically significant influence on SS productivity, since the time spent throwing and rolling logs may be considerably longer than the travel time. Further, in terms of extraction activity, there was no common pattern across Korea for selecting SS operations in steeply-sloped forests.

\section{Conclusions}

In conclusion, this study's findings showed that SS efficiency in extracting 2-4 $\mathrm{m}$ logs from stumps to roadside/landing areas varied across harvest units in mountain forests. The mean productivity was $6.03 \pm 1.90 \mathrm{~m}^{3} / \mathrm{SMH}$, with a minimum of $2.44 \mathrm{~m}^{3} / \mathrm{SMH}$ and maximum of $9.85 \mathrm{~m}^{3} / \mathrm{SMH}$. According to the cost deduction, the corresponding extraction costs were estimated to be from US $\$ 4.37$ to $17.66 / \mathrm{m}^{3}$. Productivity was significantly impacted by DBH, tree volume, and TTD, whereas stand density and slope were observed to be non-significant.

Assessing the productivity of forest operations is a challenging task due to rough and unstructured environmental conditions. In this study, an SS productivity prediction model was derived using follow-up data taken from 30 forest sites across South Korea. Two-thirds of the total dataset were used to build the model, while the remaining one-third of the data was used for validation. This model is expected to be used by harvest planners, forest managers, and decision makers to improve SS management and extraction operations. However, these results were limited to applications across South Korea. Further study is needed using a broader and more updated range of data with a tree volume greater than $0.6 \mathrm{~m}^{3}$ to develop an applicable prediction model that can be used in other countries.

Author Contributions: Conceptualization, E.L., S.H. and S.I.; Data collection and curation, E.L.; Formal analysis, E.L.; Funding acquisition, S.H. and S.I.; Investigation, S.H. and S.I.; Methodology, E.L., S.H. and S.I.; Writing-original draft, E.L.; Writing-review \& editing, S.H. and S.I.

Funding: This research was funded by the Korea Forest Service (Korea Forestry Promotion Institute), grant number 2013069B10-1919-AA03. 
Conflicts of Interest: The authors declare no conflict of interest.

\section{References}

1. Senturk, N.; Ozturk, T.; Demir, M. Productivity and costs in the course of timber transportation with the Koller K300 cable system in Turkey. Biosyst. Eng. 2007, 42, 2107-2113. [CrossRef]

2. Eroğlu, H.; Ozkaya, M.S.; Acar, H.H.; Karaman, A.; Yolasiğmaz, H.A. An investigation on roundwood extraction of Fagus orientalis lipsky, Abies nordmanniana (Stew.) Spach. and Picea orientalis (L.) Link. by Urus Mill forest skyline on snow. Afr. J. Biotechnol. 2009, 8, 1082-1089.

3. Gumus, S.; Ascar, H.H. Evaluation of consecutive skylines yarding and gravity skidding systems in primary forest transportation on steep terrain. J. Environ. Biol. 2010, 31, 213-218. [PubMed]

4. Melemez, K.; Tunay, M.; Emir, T. A comparison of productivity in five small-scale harvesting systems. Small Scale For. 2014, 13, 35-45. [CrossRef]

5. Stankić, I.; Poršinsky, T.; Tomašić, Ž.; Tonković, I.; Frntić, M. Productivity models for operational planning of timber forwarding in Croatia. Croat. J. For. Eng. 2012, 33, 61-78.

6. Visser, R.; Stampfer, K. Expanding ground-based harvesting onto steep terrain: A review. Croat. J. For. Eng. 2015, 36, 321-331.

7. Kulak, D.; Stańczykiewicz, A.; Szewczyk, G. Productivity and time consumption of timber extraction with a grapple skidder in selected pine stands. Croat. J. For. Eng. 2017, 38, 55-63.

8. Proto, A.R.; Skoupy, A.; Macri, G.; Zimbalatti, G. Time consumption and productivity of a medium size mobile tower yarder in downhill and uphill configurations: A case study in Czech Republic. J. Agric. Eng. 2016, 47, 216-221. [CrossRef]

9. Spinelli, R.; Magagnotti, N.; Lombardini, C. Performance, capability and costs of small-scale cable yarding technology. Small Scale For. 2010, 9, 123-135. [CrossRef]

10. Lee, E.; Im, S.; Han, S.-K. Productivity and cost of a small-scale cable yarder in an uphill and downhill area: A case study in South Korea. For. Sci. Technol. 2018, 14, 16-22. [CrossRef]

11. Wang, J.; Long, C.; McNeel, J. Production and cost analysis of a feller-buncher and grapple skidder in central Appalachian hardwood forests. For. Prod. J. 2004, 54, 159-167.

12. Standards for Time Studies for the South African Forest Industry. Available online: http://www. forestproductivity.co.za/?page_id=678 (accessed on 17 August 2018).

13. Kellogg, L.D.; Bettinger, P. Thinning productivity and cost for a mechanized cut-to-length system in the north-west Pacific Coast region of the USA. J. For. Eng. 1994, 5, 43-53.

14. She, J.; Chung, W.; Kim, D. Discrete-event simulation of ground-based timber harvesting operations. Forests 2018, 9, 683. [CrossRef]

15. Olsen, E.; Kellogg, L. Comparison of time-study techniques for evaluating logging production. Trans. ASAE 1983, 26, 1665-1668. [CrossRef]

16. Strandgard, M.; Mitchell, R. Automated time study of forwarders using GPS and a vibration sensor. Croat. J. For. Eng. 2015, 36, 175-184.

17. Sirén, M.; Aaltio, H. Productivity and costs of thinning harvesters and harvester-forwarders. Int. J. For. Eng. 2003, 14, 39-48. [CrossRef]

18. Spinelli, R.; Hartsough, B.R.; Magagnotti, N. Productivity Standards for Harvesters and Processors in Italy. For. Prod. J. 2010, 60, 226-235. [CrossRef]

19. Eriksson, M.; Lindroos, O. Productivity of harvesters and forwarders in CTL operations in northern Sweden based on large follow-up datasets. Int. J. For. Eng. 2014, 25, 179-200. [CrossRef]

20. Korea Forest Service. Available online: https://www.forest.go.kr (accessed on 10 October 2018).

21. Cho, K.-H.; Cho, M.-J.; Han, H.-S.; Han, S.-K.; Cha, D.-S. Harvesting cost of tree-length thinning in a Larix leptolepis stands. J. Korean For. Soc. 2015, 104, 221-229. [CrossRef]

22. Cho, M.; Cho, K.; Choi, B.; Cha, D. Yarding productivity of tree-length harvesting using small cable-yarder in steep slope, South Korea. For. Sci. Technol. 2018, 14, 132-137. [CrossRef]

23. Han, W.S.; Han, H.-S.; Kim, N.-H.; Cha, D.S.; Cho, K.S.; Min, D.H.; Kwon, K.C. Comparison of harvesting productivity and cost of cable yarding systems. J. Korean For. Soc. 2014, 103, 87-97. [CrossRef]

24. Kim, M.-K.; Baek, S.-A.; Cho, K.-H.; Jung, D.-H. Productivity, cost, and optimal forest road network density of tree-length yarding operations with tower yarder. J. Korean For. Soc. 2017, 106, 300-309. 
25. Han, W.S.; Han, H.-S.; Kim, Y.-S.; Shin, M.Y. The yarding productivity and cost cable yarding operation by yarder attached on tractor: Using the Chuncheon tower-yarder. J. Korean For. Soc. 2008, 97, 641-649.

26. Spinelli, R.; Visser, R.; Thees, O.; Sauter, H.; Krajnc, N.; Riond, C.; Magagnotti, N. Cable logging contract rates in the Alps: The effect of regional variability and technical constraints. Croat. J. For. Eng. 2015, 36, $195-203$.

27. Eroğlu, H.; Acar, H.H.; Ozkaya, M.S.; Tilki, F. Using plastic chutes for extracting small logs and short pieces of wood from forests in Artvin, Turkey. Build. Environ. 2007, 42, 3461-3465. [CrossRef]

28. Lee, E.; Li, Q.; Eu, S.; Im, S. Assessing the impacts of traditional mechanized logging operations on soil physical and hydrological properties in the Republic of Korea. Heliyon 2019. under review.

29. Miyata, E.S. Determining Fixed and Operating Costs of Logging Equipment; General Technical Report Nr. NC-55; Northern Central Forest Experiment Station, US Forest Service: Saint Paul, MN, USA, 1980; p. 16.

30. Kim, M.-K.; Park, S.-J. An analysis of the operational time and productivity in whole-tree and cut-to-length logging operation system. J. Korean For. Soc. 2012, 101, 344-355.

31. Lee, C.G.; Choi, Y.S.; Ju, Y.M.; Lee, S.Y.; Nam, Y.S.; Cho, L.H.; Kim, J.M.; Oh, K.C.; Cho, M.J.; Lee, E.J.; et al. A study on the productivity and cost analysis of the timber and logging residue in CTL system of excavator yarding for using the woody resources. Korean Soc. New Renew. Energy 2016, 12, 51-58. [CrossRef]

32. Kaakkurivaara, N.; Kaakkurivaara, T. Productivity and cost analysis of three timber harvesting extraction methods on steep terrain in Thailand. Croat. J. For. Eng. 2018, 39, 213-221.

33. Sowa, J.M.; Szewczyk, G. Time consumption of skidding in mature stands performed by winches powered by farm tractor. Croat. J. For. Eng. 2013, 34, 255-265.

34. Hiesl, P.; Benjamin, J.G. Applicability of international harvesting equipment productivity studies in Maine, USA: A literature review. Forests 2015, 4, 898-921. [CrossRef]

35. Lindroos, O.; Cavalli, R. Cable yarding productivity models: A systematic review over the period 2000-2011. Int. J. For. Eng. 2016, 27, 79-94. [CrossRef]

36. Session, J.; Boston, K. Optimization of road spacing for log length shovel logging on gentle terrain. Int. J. For. Eng. 2006, 17, 67-75. [CrossRef]

37. Landford, B.L.; Stokes, B.J. Comparison of two thinning systems. Part 2. Productivity and costs. For. Prod. J. 1996, 46, 47-53.

38. Jiroušek, R.; Klvač, R.; Skoupý, A. Productivity and costs of the mechanized cut-to-length wood harvesting system in clear-felling operations. J. For. Sci. 2007, 53, 476-482. [CrossRef]

39. Visser, R.; Spinelli, R. Determining the shape of the productivity function for mechanised felling and felling-processing. J. For. Res. 2012, 17, 397-402. [CrossRef]

40. Mederski, P.S.; Bembenek, M.; Karaszewski, Z.; Łacka, A.; Szczepańska-Álvarez, A.; Rosińska, M. Estimating and modelling harvester productivity in pine stands of different ages, densities and thinning intensities. Croat. J. For. Eng. 2016, 37, 27-36.

41. Berendt, F.; Fortin, M.; Suchomel, C.; Schweier, J. Productivity, costs, and selected environmental impacts of remote-controlled mini forestry crawlers. Forests 2018, 9, 591. [CrossRef]

42. Han, H.; Chung, W.; She, J.; Anderson, N.; Wells, L. Productivity and costs of two beetle-kill salvage harvesting methods in northern Colorado. Forests 2018, 9, 572. [CrossRef]

43. Ghaffariyan, M.R.; Stampfer, K.; Sessions, J. Forwarding productivity in Southern Austria. Croat. J. For. Eng. 2007, 28, 169-174.

44. Strandgard, M.; Mitchell, R.; Acuna, M. Time consumption and productivity of a forwarder operating on a slope in a cut-to-length harvest system in a Pinus radiata D. Don pine plantation. J. For. Sci. 2017, 63, 324-330.

45. Spinelli, R.; Cacot, E.; Mihelic, M.; Nestorovski, L.; Mederski, P.; Tolosana, E. Techniques and productivity of coppice harvesting operations in Europe: A meta-analysis of available data. Ann. For. Sci. 2016, 73, 1125-1139. [CrossRef]

46. Nurminen, T.; Korpunen, H.; Uusitalo, J. Time consumption analysis of the mechanized cut-to-length harvesting system. Silva Fenn. 2006, 40, 335-363. [CrossRef]

47. Danilović, M.; Stojnić, D.; Karić, S.; Sućević, M. Transport of technical roundwood by forwarder and tractor assembly from poplar plantation. Nova Mech. Šumarstva 2014, 35, 11-21.

48. Matthews, G.; Dorn, L.; Hoyes, T.W.; Davies, D.R.; Glendon, A.I.; Taylor, R.G. Driver stress and performance on a driving simulator. Hum. Factors 1998, 40, 136-149. [CrossRef] [PubMed] 
49. Kumazawa, Y.; Fujita, M.; Yamasaki, A.; Koyama, K.; Ichihara, K.; Oka, M. Consideration about safety and efficient log transportation by forwarders. J. Jpn. For. Eng. Soc. 2011, 26, 181-186.

50. Berg, S.; Ersson, B.T.; Manner, J. Distance driven and driving speed when forwarding during final felling in central Sweden. J. For. Sci. 2019, 6, 183-194. [CrossRef]

51. Adebayo, A.B.; Han, H.-S.; Johnson, L. Productivity and cost of cut-to-length and whole-tree harvesting in a mixed-conifer stand. For. Prod. J. 2007, 57, 59-69.

52. Norihiro, J.; Ackerman, P.; Spong, B.D.; Längin, D. Productivity model for cut-to-length harvester operation in South African Eucalyptus pulpwood plantations. Croat. J. For. Eng. 2018, 39, 1-13.

53. Ghaffariyan, M.R.; Sessions, J.; Brown, M. Machine productivity and residual harvesting residues associated with a cut-to-length harvest system in southern Tasmania Southern Forests. J. For. Sci. 2012, 74, 229-235.

54. Walsh, D.; Strandgard, M. Productivity and cost of harvesting a stemwood biomass product from integrated cut-to-length harvest opeartions in Australian Pinus radiata plantations. Biomass Bioenergy 2014, 66, 93-102. [CrossRef]

(C) 2019 by the authors. Licensee MDPI, Basel, Switzerland. This article is an open access article distributed under the terms and conditions of the Creative Commons Attribution (CC BY) license (http://creativecommons.org/licenses/by/4.0/). 